\title{
The Role of Regulatory Agencies and Intellectual Property: Part II
}

\author{
Kevin E. Noonan \\ McDonnell Boehnen Hulbert \& Berghoff, LLP, Chicago, Illinois 60606-6709 \\ Correspondence: noonan@mbhb.com
}

Patent law and antitrust law have traditionally been areas of the law involving at least some inherent tension. Champions of antitrust argue that the patent "monopoly" must be strictly limited as an exception to the general legal principle that competition should be unfettered. Patent lawyers argue that patents are the result of an exercise of congressional authority, enshrined in the Constitution, reflecting the policy decision by the Founders that granting a limited exclusionary right was justified by the public benefits derived from full disclosure of the patented invention. In the modern era these competing values have played out in the context of so-called ANDA litigation, involving disputes between branded pharmaceutical companies and generic competitors. Settlement of such litigation has been identified by the Federal Trade Commission (FTC), and private parties encouraged by the FTC's position, as an antitrust violation, in large part because such settlements are viewed as frustrating the congressional purpose in promoting early generic competition. After almost a decade of fighting these battles in the federal courts, the Supreme Court addressed the issue directly. The result is that such settlements are not per se illegal but are also not protected by the presumption of patent validity for activities within the "scope of the patent." Rather, the court decided that these agreements should be assessed for antitrust liability under the "rule of reason" used in other antitrust contexts.

\section{THE INTERSECTION OF PATENT INFRINGEMENT AND ANTITRUST LIABILITY IN ANDA LITIGATION}

battle has been raging over the past 10 years Aregarding the competing interests of patent protection and antitrust prohibitions in the specialized area of law concerned with patented drugs regulated by the Food and Drug Administration (FDA). ${ }^{1}$ The contestants have been the

${ }^{1}$ The Drug Price Competition and Patent Term Adjustment Act of 1984, Public Law No. 98-417, 98 Stat. 1585 (codified
Federal Trade Commission (FTC) and parties to so-called ANDA (Abbreviated New Drug Application) litigation, which is brought between a branded drug company and a generic challenger. ${ }^{2}$ These two prior adversaries have

at 21 U.S.C. $\$ 355(\mathrm{~b}),(\mathrm{j}),(1) ; 35$ U.S.C. $\$ \$ 156,271,282$ ) (hereinafter the Hatch-Waxman Act).

${ }^{2}$ The Hatch-Waxman Act makes it an act of infringement to file an ANDA with the FDA in the face of an innovator having regulatory approval to market a drug and a patent or patents on said drug, a formulation of the drug, or methods of making or using the drug (35 U.S.C. $\$ 271(\mathrm{e})(2)(\mathrm{A})$ ).

Editors: Salim Mamajiwalla and Rochelle Seide

Additional Perspectives on Intellectual Property in Molecular Medicine available at www.perspectivesinmedicine.org

Copyright (C) 2015 Cold Spring Harbor Laboratory Press; all rights reserved; doi: 10.1101/cshperspect.a020834

Cite this article as Cold Spring Harb Perspect Med 2015;5:a020834 


\section{K.E. Noonan}

generally been defendants, in complaints not only by the FTC but by consumer groups, drug wholesalers and retailers, and states' attorneys general, all alleging that the ANDA litigation parties have violated the antitrust laws by settling ANDA litigation. The gravamen of this complaint is that the branded drug maker has generally settled with the generic challenger on terms in which the generic company is either paid money or otherwise granted something of economic value in exchange for refraining from entering the marketplace as early as it would have if the generic company had prevailed in the litigation; these agreements have been termed "reverse payment" or "pay-for-delay" settlement agreements. On the other hand, the generic drug generally has entered the marketplace sooner than it would have been otherwise able if it had lost the ANDA litigation. However, the FTC and others have contended that the payment from the branded to the generic drug maker indicates an acknowledgment (or admission) that the patent(s) at issue is "weak" or otherwise subject to invalidation or a finding of unenforceability, and thus any delay in generic drug entry is anticompetitive and a violation of the antitrust laws. ${ }^{3}$

This past term the Supreme Court resolved the question of the legality of reverse payment settlement agreements in FTC v. Actavis, Inc. (133 S. Ct. 2223, 186 L. Ed. 2d 343) (2013). Although not finding such agreements to be presumptively illegal, the court held that they were susceptible to antitrust scrutiny and should be evaluated under a "rule of reason" analysis. In so holding, the court overruled the majority of courts of appeal that had deemed the practice free of antitrust implications, for reasons directly related to the nature of the activities giving rise to such litigation and the exclusivity rights conferred by patents.

\footnotetext{
${ }^{3}$ Including, inter alia, $\$ \$ 1$ and 2 of the Sherman Act (Sherman Act, July 2, 1890, ch. 647, 26 Stat. 209 (codified at 15 U.S.C. $\$ \$ 1-7)$ ) and $\$ 5$ of the Clayton Act (Clayton Antitrust Act of 1914, Public Law No. 63-212, 38 Stat. 730 enacted October 15, 1914 (codified at 15 U.S.C. \$\$ 12-27; 29 U.S.C. $\$ \$ 52-53)$ ).
}

Litigation under 35 U.S.C. §271(e)(2) (the Hatch-Waxman Act)

A specialized area of particular focus in the intersection of patent and antitrust law is socalled ANDA litigation under the Hatch-Waxman Act.

\section{ANDA Litigation Basics}

The Drug Price Competition and Patent Term Restoration Act (the Hatch-Waxman Act) makes it an act of infringement to file an ANDA with the FDA in the face of an innovator having regulatory approval to market a drug and a patent or patents on said drug, a formulation of the drug, or methods of making or using the drug (35 U.S.C. $\$ 271(\mathrm{e})(2)(\mathrm{A})$ ). Generally, generic drug makers filing an ANDA trigger this infringement provision by asserting that the patent or patents listed with the FDA for an innovator drug (in a listing known as the Orange Book) are not infringed, invalid, or unenforceable. The patentee then has 45 days to file suit, and if she does so invokes a 30-month stay in any approval of the generic drug maker's ANDA by the FDA.

The nature of this litigation is unlike any other patent infringement case. The accused infringer is not on the market and accordingly is not at risk for a damages assessment, and has not put investment at the risk of an injunction. As noted by the Eleventh Circuit in Schering-Plough Corporation v. Federal Trade Commission (402 F.3d 1056, 1073-74) (11th Cir. 2005):

It is uncontested that parties settle cases based on their perceived risk of prevailing in and losing the litigation. Pre-Hatch-Waxman, [the generic challengers] normally would have had to enter the market with their products, incurring the costs of clinical trials, manufacturing and marketing. This market entry would have driven down [the patentee]'s profits, as it took sales away. As a result, [the patentee] would have sued [the generic challengers], seeking damages for lost profits and willful infringement. Assuming the patent is reasonably strong, and the parties then settled under this scenario, the money most probably would flow from the infringers to [the patentee] because the generics would 
have put their companies at risk by making infringing sales.

In ANDA litigation, it is the patentee who has all the risk, specifically that her patent will be found invalid or unenforceable. As a consequence, there has developed over the past decade a greater tendency for the patentee/drug innovator to settle ANDA litigation on terms in which the generic challenger enters the marketplace later than she would have if she had prevailed in the litigation but generally earlier than if she had lost, with the exchange of cash or other payment of value from the patentee to the accused infringer. This situation has raised antitrust concerns from consumers, but most especially by the FTC, from which several suits have originated or which has participated as a plaintiff or amicus.

\section{The FTC's Positions}

The FTC's original position was that these agreements are per se violations of $\$ 1$ of the Sherman Act as naked agreements in restraint of trade. Accordingly, the commission called for an outright ban on such agreements. ${ }^{4}$ Having universally lost in the courts on this theory, as set forth in more detail below, the commission has moderated its position, advocating that they are presumptively illegal and should be reviewed for antitrust liability under the rule of reason.

The FTC's reasoning and the basis for its crusade against such practices are as follows. First, generic competition decreases the costs of drugs to consumers and, more importantly, to the federal government, the largest drug purchaser in the country, if not the world. Second, generic drug companies are motivated under the Hatch-Waxman Act to challenge patents, because the "first to file" an ANDA with a certification that the generic product does not in-

\footnotetext{
${ }^{4}$ See Federal Trade Commission, Pay-for-Delay: How Drug Company Pay-Offs Cost Consumers Billions, at 2 (2010), www .ftc.gov/sites/default/files/documents/reports/pay-delayhow-drug-company-pay-offs-cost-consumers-billions-feder al-trade-commission-staff-study/100112payfordelayrpt.pdf (hereinafter Pay-for-Delay Report).
}

fringe or that the innovator's patents are invalid or unenforceable garners a 180-day exclusivity period as the only generic on the market. Third, reverse payment settlements upset the statutory arrangement, permitting "bad" patents to remain in force and delaying generic entry. Fourth, generic drug companies prevailed in ANDA litigation against brand-name drug companies $75 \%$ of the time between 1992 and 2002. ${ }^{5}$ Finally, the FTC contends that branded drug companies enter into reverse payment arrangements because they know that their patents are invalid and/or unenforceable and the agreements permit them to undeservedly collect "monopoly" profits (this conclusion has been almost universally rejected by the courts of appeal until very recently $\left.^{6}\right)$. $^{7}$

The factual underpinnings of the FTC's contentions that reverse payment settlement agreements of ANDA litigation require antitrust scrutiny are set forth in most detail in a series of reports on the subject; those issued in 20102013 are illustrative. In 2010 the FTC issued a report that characterized these agreements as harming consumers while enriching both innovator and generic drug makers, in large part because of a delay in the up to $90 \%$ reduction in the cost of a branded drug upon generic competitor entry. ${ }^{8}$ The report notes that the FTC had "deterred" the use of such agreements between April 1999 and 2004, buttressed by a single decision by a regional court of appeal (In

\footnotetext{
${ }^{5}$ See Federal Trade Commission, Generic Drug Entry Prior to Patent Expiration: An FTC Study, at viii (2002) (providing incentives for brand-name companies to pursue these types of agreements).

${ }^{6}$ See Arkansas Carpenters Health \& Welfare Fund v. Bayer AG (604 F.3d 98, 105) (2d Cir. 2010); In re Ciprofloxacin Hydrochloride Antitrust Litigation (544 F.3d 1323, 1337) (Fed. Cir. 2008); In re Tamoxifen Citrate Antitrust Litigation (466 F.3d 187, 206) (2d Cir. 2006); Schering-Plough Corp. (402 F.3d at 1075-76); and Valley Drug Company v. Geneva Pharmaceuticals, Inc. (344 F.3d 1294, 1310-11) (11th Cir. 2003).

${ }^{7}$ As a result (in part) of FTC advocacy against these agreements, Congress enacted as part of the Medicare Prescription Drug, Improvement, and Modernization Act of 200342 U.S.C. $\$ 1395 \mathrm{w}-101$ (2009) note ( $\$ 110$ of the Act), 21 U.S.C. $\$ 355$ (2009) note (\$\$ 1111-1118 of the Act), 21 U.S.C. $\$ 355(\mathrm{j})(5)$ (2009) ( $\$ 1102$ of the Act), provisions requiring all such agreements to be filed with the FTC.

${ }^{8}$ Pay-for-Delay Report at 1.
} 


\section{K.E. Noonan}

re Cardizem CD Antitrust Litigation (332 F.3d 896, 915) (6th Cir. 2003)) that these agreements were per se illegal. ${ }^{9}$ However, later appellate decisions ${ }^{10}$ upheld these agreements, "misapply[ying] the antitrust law[s]," according to the FTC. ${ }^{11}$ As a consequence, the report contends that generic drug entry has been delayed for on average 17 months and pay-for-delay agreements "protect at least $\$ 20$ billion in sales of brand-name pharmaceuticals from generic competition." 12 The report estimated that the cost to American consumers was $\$ 3.5$ billion per year. $^{13}$

The 2010 report noted that there have been 66 agreements that "involved some form of compensation" for delayed entry between fiscal years 2004 and 2009, and that in the same time period ANDA litigation was settled in 152 instances without pay-for-delay agreements. ${ }^{14} \mathrm{Of}$ the 66 agreements involving delayed generic entry, 51 of them $(77 \%)$ were between the brand-name pharmaceutical company and the first ANDA filer. ${ }^{15}$ These data were significant because (as the report notes) "[s] ettlements with first-filer generics can prevent all generic entry," because the generic company to first file an ANDA has a 180-day exclusivity period to which it is entitled under the Hatch-Waxman Act. ${ }^{16}$ Thus, delaying market entry for the first ANDA filer prevents any subsequent ANDA filer from entering the market until the first filer has utilized the 180-day exclusivity period.

These agreements do not all involve direct cash payments to the generics companies, however. Other arrangements described in the report include an agreement from the brand-

\footnotetext{
${ }^{9}$ Pay-for-Delay Report at 1.

${ }^{10}$ In re Ciprofloxacin Hydrochloride Antitrust Litigation (544 F.3d at 1341); In re Tamoxifen Citrate Antitrust Litigation (466 F.3d at 216); and Schering-Plough Corp. (402 F.3d at 1076).

${ }^{11}$ Pay-for-Delay Report at 1.

${ }^{12} I d$. at 2 .

${ }^{13} I d$.

${ }^{14} I d$. at 4 .

${ }^{15} I d$. at 5 .

${ }^{16} I d$. (emphasis in original).
}

name pharmaceutical company not to introduce an "authorized generic" (AG), that is, a generic version of the drug made by the brandname company, which are not excluded by the 180-day exclusivity period awarded to the first to file an ANDA. ${ }^{17}$ These types of agreements were included in about $25 \%$ of the pay-for-delay agreements discussed in the report. ${ }^{18}$ The situation was no better a year later, and the 2011 report contained a tabulation of reverse payment settlement agreements by year up to that time. ${ }^{19}$ Finally, by the time of its 2013 report the FTC's data indicated that the "vast majority of patent settlements (greater than 70\%) continued to be resolved without compensation to the generic manufacturer." ${ }^{20}$ This trend reflects an adaptation to the FTC's campaign against these agreements, wherein the majority of agreements contain, instead of a cash payment, an agreement from the innovator not to bring an AG version of the drug to market in competition with the generic drug maker.

Not surprisingly, the FTC has taken the position that agreements involving a promise by the innovator not to market an AG should also be presumptively illegal, applying the following reasoning (see In re K-Dur Antitrust Litigation (686 F.3d 197, 207) (3rd Cir. 2012)). First, AGs "destroy[] a significant amount of the value that a generic company otherwise would ob-

\footnotetext{
${ }^{17} I d$.

${ }^{18} \mathrm{Id}$.

${ }^{19}$ Paradoxically, the report actually showed the percentage of reverse payment settlement agreements in overall decline during the period from 2003-2011; Federal Trade Commission, Agreements Filed with the Federal Trade Commission under the Medicare Prescription Drug, Improvement, and Modernization Act of 2003: Overview of Agreements Filed in FY 2011, A Report by the Bureau of Competition, at 2 (2011), www.ftc.gov/sites/default/files/documents/reports/agree ments-filed-federal-trade-commission-under-medicare-pre scription-drug-improvement-modernization/1110mma agree-2.pdf.

${ }^{20}$ Federal Trade Commission, Agreements Filed with the Federal Trade Commission under the Medicare Prescription Drug, Improvement, and Modernization Act of 2003: Overview of Agreements filed in FY 2012, A Report by the Bureau of Competition, at 2 (2013), www.ftc.gov/sites/default/files/ documents/reports/agreements-filed-federal-trade-commis sion-under-medicare-prescription-drug-improvement-and /130117mmareport.pdf.
} 
tain from [the] 180-day [] exclusivity" period. ${ }^{21}$ Second, a branded company's agreement not to market an AG "enables the generic company to maximize its revenues during the first-filer exclusivity period." 22 Finally, these "economic realities" compel the conclusion that "a no-AG commitment is without a doubt a method of paying a generic company for delayed entry." ${ }^{23}$

Despite the FTC's protestations, decisions by the courts have until recently rejected the FTC's position unless there have been additional factors that change the nature of the agreement to be on balance anticompetitive, as set forth in more detail below.

\section{DECISIONS BY CIRCUIT COURTS OF APPEAL}

Several regional circuit courts of appeal have addressed the legality of reverse payment settlement agreements, and only two (the Sixth Circuit and, more recently, the Third Circuit) found that the agreement at issue was illegal.

The first appellate decision regarding reverse settlement payment agreements in the Sixth Circuit, In re Cardizem CD Antitrust Litigation, supported the FTC's position, but had several aspects not found in later cases in which these agreements have been upheld (see In re Cardizem CD Antitrust Litigation (332 F.3d 896) (6th Cir. 2003)). This case ${ }^{24}$ involved a reverse payment-containing settlement agreement $^{25}$ in ANDA litigation over a patent ${ }^{26}$

\footnotetext{
${ }^{21}$ Federal Trade Commission's Motion for Leave to File Amicus Curiae Brief at 5, In re Effexor XR Antitrust Litigation (No. 3:11-cv-05479) (D. N.J. Aug. 10, 2012).

${ }^{22}$ Id. at 7 .

${ }^{23} I d$. at 9 .

${ }^{24}$ The suit was brought by a variety of patient groups as plaintiffs against HMR and Andrx. Id. at 900.

${ }^{25}$ The terms of the agreement included that Andrx would not market a generic version of Cardizem CD until Andrx received a final determination in its favor in the patent infringement lawsuit, HMR or Andrx entered into a licensing agreement, or HMR entered into a licensing agreement with a third party (the trigger date being the earliest of these). Id. at 902. Andrx agreed to dismiss its counterclaims (for unfair competition and antitrust violations). Andrx further agreed to pursue its ANDA and not to relinquish or transfer its 180day exclusivity period or any other right; and HMR agreed to pay Andrx $\$ 40$ million per year ( paid \$10 million every
}

for Hoechst Marion Roussel's (HMR) Cardizem CD product. ${ }^{27}$ The agreement contained a number of provisions not found in other legal agreements. ${ }^{28}$ The antitrust lawsuit was brought under $\$ 1$ of the Sherman Act and $\$ 4$ of the Clayton Act (including its treble damages provisions), based on the "but for" argument that a generic Cardizem would have been on the market absent the agreement, and that the exercise of its 180-day exclusivity barred other generics from coming to market. ${ }^{29}$ The district court

calendar quarter) beginning on the date when the FDA approved Andrx's ANDA, and \$100 million per year (less the interim \$40 million payments) once either there was a final judgment that the listed patent was not infringed, or HMR dismissed the patent infringement lawsuit, or there was another resolution of the lawsuit between the parties that did not finally resolve issues of invalidity, unenforceability, or infringement, and HMR did not refile or pursue the lawsuit. In addition, HMR agreed not to seek preliminary injunctive relief during the ANDA suit. Id. at 902-03. Pursuant to the terms of the agreement, HMR paid Andrx the $\$ 40$ million per year payment in $\$ 10$ million quarterly payments. Id. at 903. Andrx then filed a supplement to its ANDA specifying that it had reformulated the product and certified that its reformulated product did not infringe the claims of HMR's patent. The FDA approved this reformulated product, and the parties settled the infringement suit and terminated the agreement. HMR also paid Andrx a final sum of \$50.7 million, for a total of payments equaling $\$ 89.83$ million. Two weeks later Andrx began to market its generic product, starting the 180-day exclusivity period. This date of market entry was almost 12 years before the expiration date of the ' 584 patent. Id. at 903 .

${ }^{26}$ U.S. Patent No. 5,470,584.

${ }^{27}$ In re Cardizem CD Antitrust Litigation (332 F.3d at 902, 904) (6th Cir. 2003). The active ingredient in Cardizem is diltiazem hydrochloride, used for treating angina and hypertension and as a preventative for heart attack and stroke.

${ }^{28}$ For example, Andrx was the first ANDA filer, and the agreement did not require the generic company to change its Paragraph IV certification. Because the parties settled the ANDA litigation, the 180-day exclusivity period could not begin to run until Andrx entered the marketplace-a date delayed by the agreement. Moreover, the agreement contained a provision wherein Andrx agreed neither to relinquish nor transfer its right to the exclusivity period. $I d$. at 902. In addition, the agreement purportedly covered generic Cardizem products that did not satisfy the dissolution limitations in the patent claims and thus did not infringe the '584 patent. Id. at 915.

${ }^{29} \mathrm{Id}$. at 904 . The antitrust lawsuit against HMR and Andrx was consolidated from a number of complaints from individuals, states, and other groups. Plaintiffs fell into three categories: (1) the "State Law Class Plaintiffs," indirect purchasers, and class representatives, from various states (California, Michigan, Minnesota, New York, North Carolina, Tennessee, and Wisconsin and the District of Columbia) 


\section{K.E. Noonan}

held that the agreement was per se illegal, because the reverse payment provisions and actual payments from HMR to Andrx delayed generic entry and constituted a naked, horizontal restraint of trade, ${ }^{30}$ and certified an interlocutory appeal to the Sixth Circuit on the question of whether the reverse payment settlement was an antitrust violation (In re Cardizem CD Antitrust Litigation (332 F.3d at 900)). ${ }^{31}$

In its opinion the appellate court noted that although the literal meaning of $\$ 1$ of the Sherman Act would render per se illegal every agreement in restraint of trade, the Supreme Court has "long recognized" that the statute is meant only to prohibit unreasonable restraints and that courts assess whether a restraint is unreasonable using a rule of reason. ${ }^{32}$ However, there are some agreements that "have such predictable and pernicious anticompetitive effect[s], and such limited potential for procompetitive benefit," that they are "deemed unlawful per se." ${ }^{33}$ Courts have recognized that certain kinds

whose complaints, initially filed in state court and then removed to federal district court by defendants, alleged violations of state antitrust and consumer protection statutes; (2) the "Sherman Act Class Plaintiffs," direct purchasers, and class representatives, whose complaint, filed in federa district court, alleged a violation of federal antitrust law; and (3) the "Individual Sherman Act Plaintiffs," two groups of purchasers (filed by The Kroger Co., Albertson's, Inc., The Stop and Shop Supermarket Co., and Eckerd Corp. and by CVS Meridian, Inc. and Rite Aid Corp.), not representatives of any class, whose complaints, also filed in federal district court, alleged violations of federal antitrust law; the plaintiffs from seven states (California, Michigan, Minnesota, New York, North Carolina, Tennessee, and Wisconsin) and the District of Columbia claimed violations of state antitrust law. See In re Cardizem CD Antitrust Litigation (105 F.Supp.2d 682, 689) (E.D. Mich. 2000).

${ }^{30} I d$. at $705-06$.

${ }^{31}$ The court certified the following question for interlocutory appeal to the Sixth Circuit: "In determining whether Plaintiffs' motions for partial judgment were properly granted, whether the Defendants' September 24, 1997 Agreement constitutes a restraint of trade that is illegal per se under section 1 of the Sherman Antitrust Act, 15 U.S.C. $\$ 1$, and under the corresponding state antitrust laws at issue in this litigation."

${ }^{32} I d$. at 906 ("Under this approach, the 'finder of fact must decide whether the questioned practice imposes an unreasonable restraint on competition, taking into account a variety of factors, including specific information about the relevant business, its condition before and after the restraint was imposed, and the restraint's history, nature, and effect." [quoting State Oil Co. v. Khan (522 U.S. 3, 10) (1997)]). of agreements cannot satisfy the rule of reason under any circumstances, and such agreements have a "conclusive presumption" of illegality. ${ }^{34}$ For such agreements "no consideration is given to the intent behind the restraint, to any claimed pro-competitive justifications, or to the restraint's actual effect on competition," the court opined. ${ }^{35}$ The Supreme Court is cited as being almost dismissive of such instances: "a per se rule reflects the judgment that such cases are not sufficiently common or important to justify the time and expense necessary to identify them."36

With this analytical framework in mind, the Sixth Circuit listed facts it termed "undisputed and dispositive." ${ }^{37}$ First, under the agreement, HMR was assured that Andrx, at the time the only potential competitor in the marketplace, would remain off the market at a cost of $\$ 10$ million per quarter even after Andrx had obtained FDA approval for its generic version of the drug. ${ }^{38}$ Second, as a consequence of this agreement not only Andrx but all other generic competitors were kept off the market in view of Andrx's 180-day exclusivity period and the provisions of the agreement that Andrx would not relinquish or transfer the right (which commenced only when Andrx first entered the marketplace; thus there was a direct nexus between the agreement's provisions keeping Andrx off the market and the delay in generic Cardizem

\footnotetext{
${ }^{33} I d$. at 906 (quoting State Oil Co. (522 U.S. at 10)).

${ }^{34}$ Id. (quoting Arizona v. Maricopa County Medical Society (457 U.S. 332, 344) (1982)).

${ }^{35}$ Id. (citing National Collegiate Athletic Association v. Board of Regents of the University of Oklahoma (468 U.S. 85, 100) (1984)).

${ }^{36} I d$. at 907 (quoting Continental T.V., Inc. v. GTE Sylvania, Inc. (433 U.S. 36, 50 n.6) (1977)); see also id. (quoting United States v. Topco Associates, Inc. (405 U.S. 596, 608) (1972)). (This type of agreement is defined as "an agreement between competitors at the same level of the market structure to allocate territories in order to minimize competition," stating that " $t]$ his Court has reiterated time and time again that horizontal territorial limitations ... are naked restraints of trade with no purpose except stifling of competition. Such limitations are per se violations of the Sherman Act.")

${ }^{37} I d$.

${ }^{38} I d$. at 907 .
} 
coming to the marketplace from any source). ${ }^{39}$ This was enough for the court to characterize this as a naked, horizontal restraint that is per se illegal. ${ }^{40}$ The Sixth Circuit was not persuaded by the arguments to the contrary. Specifically, the court rejected the defendants' argument that the agreement was a proper exercise of the patent right. ${ }^{41}$ All these considerations mitigated against the parties to the agreement, which the court affirmed was illegal under the Sherman Act.

Decisions in the Second Circuit (In re Tamoxifen Citrate Antitrust Litigation (466 F.3d 187) (2d Cir. 2006), abrogated by FTC v. Actavis, Inc. (133 S. Ct. 2223) (U.S. 2013) ${ }^{42}$ and Arkan-

\footnotetext{
${ }^{39} I d$. at $907-08$.

${ }^{40} I d$. at $908.906 \mathrm{n} .11$. In a footnote the court addressed the consequences of a per se determination, instead of applying a "rule of reason" analysis:
}

The risk that the application of a per se rule will lead to the condemnation of an agreement that a rule of reason analysis would permit has been recognized and tolerated as a necessary cost of this approach. See, e.g., Maricopa Cty. ("As in every rule of general application, the match between the presumed and the actual is imperfect. For the sake of business certainty and litigation efficiency, we have tolerated the invalidation of some agreements that a full-blown inquiry might have proved to be reasonable."); Topco Assocs., Inc. ("Whether or not we would decide this case the same way under the rule of reason used by the District Court is irrelevant to the issue before us.").

Id. at 906 n.11.

${ }^{41} I d$. at 908 ("[T] he Agreement cannot be fairly characterized as merely an attempt to enforce patent rights or an interim settlement of the patent litigation. As the plaintiffs point out, it is one thing to take advantage of a monopoly that naturally arises from a patent, but another thing altogether to bolster the patent's effectiveness in inhibiting competitors by paying the only potential competitor $\$ 40$ million per year to stay out of the market."). And arguments that there were procompetitive effects that offset the anticompetitive effects were unavailing because of the court's determination that the agreement was per se illegal.

${ }^{42}$ In this case the FTC (representing multiple plaintiffs) sued a number of related companies (collectively, Zeneca) and Barr Pharmaceuticals over a settlement agreement of ANDA litigation regarding the breast cancer drug tamoxifen. The reverse payment amounted to \$21 million and an agreement between the companies wherein Barr became the source of an AG version of the drug, that is, that Zeneca would act as a supplier of tamoxifen for Barr to be resold in the United States at a price higher than would typically occur when a generic version of a drug enters the marketplace. The district court dismissed the complaint based on sas Carpenters Health \& Welfare Fund v. Bayer $A G^{43}$ ), Eleventh Circuit (Valley Drug Company v. Geneva Pharmaceuticals, Inc. (344 F.3d 1294,

the existence of a patent, on the grounds that only by misusing a patent can the patentee be liable for an antitrust violation. In re Tamoxifen Citrate Antitrust Litigation (277 F.Supp.2d 121, 124) (E.D.N.Y. 2003) (affirmed, 466 F.3d 187) (2d Cir. 2006). An additional fact relevant to the district court's later-vacated decision was that Barr, the first ANDA filer, reasserted its 180 -day data exclusivity period that prevented other generics prepared to enter the market from doing so. Prior to Barr's action, several other generic companies filed ANDAs and Zeneca prevailed in all of these lawsuits. The FDA permitted Barr to recoup its 180-day exclusivity period, which was subsequently challenged and overturned by the district court. The FTC's position was that the settlement agreement (and the district court's vacatur of the underlying ANDA litigation) amounted to "reviving" an invalid patent, continuing Zeneca's "monopoly" over tamoxifen; prevented other generics from entering the marketplace; maintained a high price on tamoxifen; and amounted to the companies "sharing [] unlawful monopoly profits." In re Tamoxifen Citrate Antitrust Litigation (466 F.3d at 196-97)

${ }^{43}$ See 604 F.3d 98 (2d Cir. 2010). In this case the drug at issue was ciprofloxacin (Cipro), a patented (U.S. Patent No. $4,670,444)$ antibiotic owned by Bayer. $I d$. at 100 . The other defendants were generic drug makers capable of making generic versions of Cipro that had filed ANDAs with the FDA to obtain regulatory approval for selling generic Cipro. Under the provisions of the Hatch-Waxman Act, Bayer sued each of these generic drug makers to block FDA approval until the conclusion of the patent litigation. 35 U.S.C. $\$ 271(\mathrm{e})(2)(\mathrm{A})$. The court recognized that "the Hatch-Waxman Act redistributes the relative risks between the patent holder and the generic manufacturer, allowing generic manufacturers to challenge the validity of the patent without incurring the costs of market entry or the risks of damages from infringement." Id. at 101. The panel's opinion cited the earlier determination that such "reverse payments" were not illegal in Joblove v. Barr Laboratories, Inc. (In re Tamoxifen Citrate Antitrust Litigation) (466 F.3d 187, 208-12) (2d Cir. 2005). The terms of the reverse settlement agreement between Bayer and Barr (the first ANDA filer) had Bayer paying Barr \$49.1 million in a lump sum and then quarterly payments of from $\$ 12.5$ million to $\$ 17.125$ million until 6 months prior to patent expiry (for a total payment of \$398.1 million), and a guarantee that the generic manufacturers could sell "brand name" Cipro for 6 months prior to the expiration date of the patent. Id. at 102. Bayer received Barr's promise (and the promise of the other generic manufacturers) not to enter the marketplace with a generic version of Cipro and concessions regarding the validity and enforceability of the patent, thereby ending the ANDA lawsuit. Barr "reserved its right to reinstate its ANDA-IV [lawsuit] if Bayer's patent were later held to be invalid." Id. at 102, n.9. There were four later challenges (by Ranbaxy, Schein, Carlsbad, and Mylan) to the patent, none of which were successful in invalidating it. Id. 
K.E. Noonan

1303-04) (11th Cir. 2003), ${ }^{44}$ Schering-Plough Corporation v. Federal Trade Commission, ${ }^{45}$

${ }^{44}$ Where the court reversed a district court determination
regarding an interim settlement agreement between a
branded pharmaceutical company and a generic containing
a monthly payment (\$4.5 million) from the branded com-
pany to the generic that kept the generic drug off the market
until the underlying patent infringement suit was conclud-
ed. The district court found this per se anticompetitive. See
In re Terazosin Hydrochloride Antitrust Litigation (164
F.Supp.2d 1340, 1354) (S.D. Fla. 2000), reversed sub nom.,
Valley Drug Company v. Geneva Pharmaceuticals, Inc. (344
F.3d 1294) (11th Cir. 2003). ${ }^{45}$ See 402 F.3d 1056 (11th Cir. 2005), in which the FTC issued a "cease and desist" order prohibiting ScheringPlough from settling any patent infringement lawsuit with a generic drug company in which Schering-Plough gave the generic company "anything of value" and "agree[d] to suspend research, development, manufacture, marketing, or sales of [the generic] product." Id. at 1058. The basis of the order was the commission's determination that the settlement agreement between Schering-Plough and Upsher Pharmaceuticals (containing a reverse payment) was an unreasonable restraint of trade in violation of $\$ 1$ of the Sherman Antitrust Act, 15 U.S.C. $\$ 1$, and $\$ 5$ of the FTC Act, 15 U.S.C. $\$ 45(\mathrm{a})$. The product at issue was an extended-release formulation of a potassium supplement claimed in U.S. Patent No. 4,863,743. Id. Schering-Plough filed suit in response to Upsher's ANDA filing on a generic version of Schering-Plough's formulation product, and the parties settled before trial. The agreement contained a $\$ 60$ million initial licensing fee, $\$ 10$ million in milestone royalty payments, and $10 \%-15 \%$ running royalties on five drugs owned by the generic company, including an anticholesterol drug having an estimated net present value of $\$ 250$ million. Id. at 1060. In addition, Upsher agreed to a compromise date for market entry of its generic potassium product. The administrative law judge (ALJ) hearing the case in the first instance found both these agreements legal and dismissed the FTC complaint. Id. at 1061-62. The ALJ's reasoning was that unless the patent was invalid or the generic products did not infringe, the agreements were not violations of the antitrust laws. Significantly, the FTC adduced no evidence before the ALJ that these agreements were anything other than arm's-length transactions between the parties. The ALJ found that the FTC did not prove that, without the payment, either a better settlement agreement or litigation would have resulted in earlier generic market entry. Id. at 1061. The case was then heard by the full commission, which reversed the ALJ. The commission backed off its initial position that reverse payment agreements are per se illegal, but held that the quid pro quo of payment was for delayed generic market entry, which delay "would injure competition and consumers." Id. at 1062. The commission based its decision on generic market entry that "might have been" agreed upon between the parties in the absence of payments. Id. Although the commission could not tie the entry dates to the monetary compensation, it developed the rule that reverse payments were illegal, with an exception for litigation costs to be capped at $\$ 2$ million and a requirement that the FTC must be notified of the existence and terms of the and Federal Trade Commission v. Watson Pharmaceuticals, Inc. ${ }^{46}$ ), and Federal Circuit (In re Ciprofloxacin Hydrochloride Antitrust Litigation $^{47}$ ) Courts of Appeal came to a different conclusion. In each case the circuit court ruled against the FTC's position, based in the exclusionary power of the patent. ${ }^{48}$ This outcome persisted as the FTC changed its argument, from its initial position that reverse payment

agreement, a requirement adopted in the 2003 Medicare Prescription Drug Improvement and Modernization Act. Id. ${ }^{46}$ See 677 F.3d 1298, 1312 (11th Cir. 2012), (cert. granted, 133 S. Ct. 787) (U.S. 2012) and reversed and remanded sub nom., FTC V. Actavis, Inc. (133 S. Ct. 2223, 186 L. Ed. 2d 343) (U.S. 2013). In this case the reverse payment settlement agreement of ANDA litigation between the parties provided that the $\$ 271(\mathrm{e})(2)$ defendants would “respect" the '894 patent and that both were entitled to launch in August 2015, 5 years before the ' 894 patent was scheduled to expire. $I d$. at 1305 . In addition, Watson and Paddock agreed that their sales forces would promote Unimed's (later Solvay's) AndroGel product until the agreed time for their own product launch, and that Unimed (later Solvay) would make annual payments to the parties $(\sim 20$ million to $\$ 30$ million to Watson, $\sim \$ 10$ million to Par/Paddock); in addition, Par/Paddock agreed to supply AndroGel to Unimed (later Solvay) in a "backup capacity" for an additional $\$ 2$ million annually. Id.

${ }^{47}$ See 544 F.3d 1323, 1327 (Fed. Cir. 2008), abrogated by FTC v. Actavis, Inc. (133 S. Ct. 2223, 186 L. Ed. 2d 343) (U.S. 2013). In this case several unions and other patient groups, as well as individual patients, sued defendants including Bayer AG and Bayer Corp., HMR, Watson Pharmaceuticals, and Barr Labs over ciprofloxacin hydrochloride (Cipro), Bayer's product, with Barr being the first ANDA filer. Plaintiffs alleged antitrust violations under $\$ \$ 1$ and 2 of the Sherman Act, illegal contracts in restraint of trade, as well as under state antitrust and consumer protection laws; later plaintiffs added a Walker Process claim (despite the fact that the patent had been through a reexam with a claim specific to ciprofloxacin hydrochloride exiting unamended), but the district court granted summary judgment against the plaintiffs, holding that any anticompetitive effects "were within the exclusionary zone of [the patent]." Id. at 1333. This decision was based on a "rule of reason" analysis that did not get past the first step: any anticompetitive effects fell within the ambit of the patent exclusionary right and hence were not illegal. Id. at 1330.

${ }^{48}$ For example, in Schering-Plough the court said that patents intrinsically distort the competitive landscape, and thus defeat a determination that the agreement was per se illegal. Schering-Plough (403 F.3d at 1064) ("In the context of patent litigation ... the anticompetitive effect may be no more broad than the patent's own exclusionary power. To expose those agreements to antitrust liability would 'obviously chill such settlements" [quoting Valley Drugs (344 F.3d at 1309)]). 
settlement agreements should be per se illegal $^{49}$ to the position that these agreements should be assessed under the antitrust "rule of reason" standard. ${ }^{50}$ But when patents are involved, neither per se illegality nor a "rule of reason" analysis is appropriate in assessing antitrust liability, "because they seek to determine whether the challenged conduct had an anticompetitive effect on the market." ${ }^{\text {"1 }}$ It is the legitimate exclusionary power of the patent that must be considered in making an antitrust determination under these courts' reasoning. ${ }^{52}$ Courts have also considered the disruption in the typical dynamic between parties in patent infringement litigation in ANDA litigation between branded pharmaceutical companies and generic challengers. ${ }^{53}$ The Federal Circuit added to

${ }^{49}$ For example, the Second Circuit expressly rejected the FTC's argument that a reverse payment settlement agreement was per se unlawful. In re Tamoxifen Citrate Antitrust Litigation (466 F.3d 187, 206) (2d Cir. 2006).

${ }^{50}$ The rule "tests 'whether the restraint imposed is such as merely regulates and perhaps thereby promotes competition or whether it is such as may suppress or even destroy competition."” Schering-Plough (403 F.3d at 1064) (quoting FTC v. Indiana Federation of Dentists (476 U.S. 447, 457) (1986)).

${ }^{51} I d$. at 1065-66. ("By their nature, patents create an environment of exclusion, and consequently, cripple competition. The anticompetitive effect is already present. 'What is required here is an analysis of the extent to which antitrust liability might undermine the encouragement of innovation and disclosure, or the extent to which the patent laws prevent antitrust liability for such exclusionary effects.' Valley Drug Co. v. Geneva Pharm., Inc. (344 F.3d 1294, 1311 n.27) (11th Cir. 2003) Therefore, in line with Valley Drug, we think the proper analysis of antitrust liability requires an examination of: (1) the scope of the exclusionary potential of the patent; (2) the extent to which the agreements exceed that scope; and (3) the resulting anticompetitive effects.")

${ }^{52}$ For example, the Schering-Plough court held that the evidence before the ALJ was directly contrary to the FTC's position - that the reverse payment was "a bona fide fairvalue payment" for rights to market these drugs. Id. at 1069.

${ }^{53}$ In Schering-Plough the court noted that under typical infringement situations Schering would be entitled to lost profits damages for Upsher and ESI Lederle entering the marketplace. Id. at 1073-74. ("It is uncontested that parties settle cases based on their perceived risk of prevailing in and losing the litigation. Pre-Hatch-Waxman, Upsher and ESI normally would have had to enter the market with their products, incurring the costs of clinical trials, manufacturing and marketing. This market entry would have driven down Schering's profits, as it took sales away. As a result, Schering would have sued ESI and Upsher, seeking damages for lost profits and willful infringement. Assuming the patent is reasonably strong, and the parties then settled under their analysis that absent fraud on the Patent and Trademark Office or sham litigation, patent validity does not need to be considered in the application of a "rule of reason" analysis ${ }^{54}$ based on the presumption of validity: "the district court correctly concluded that there is no legal basis for restricting the right of a patentee

this scenario, the money most probably would flow from the infringers to Schering because the generics would have put their companies at risk by making infringing sales.") HatchWaxman essentially redistributes the relative risk assessments and explains the flow of settlement funds and their magnitude. Because of the Hatch-Waxman scheme, ESI and Upsher gained considerable leverage in patent litigation: Their exposure to liability amounted to nothing more than litigation costs, but paled in comparison to the immense volume of generic sales and resulting profits. $I$ d. at 1074 ("By entering into the settlement agreements, Schering realized the full potential of its infringement suit-a determination that the ' 743 patent was valid and that ESI and Upsher would not infringe the patent in the future. Furthermore, although ESI and Upsher obtained less than what they would have received from successfully defending the lawsuits (the ability to immediately market their generics), they gained more than if they had lost. A conceivable compromise, then, directs the consideration from the patent owner to the challengers ... Ultimately, the consideration paid to Upsher and ESI was arguably less than if Schering's patent had been invalidated, which would have resulted in the generic entry of potassium chloride supplements.") In the Tamoxifen case, the Second Circuit noted that, typically in patent litigation, the risk is with the accused infringer (the generic drug maker), who must develop the competing generic drug, obtain approval, and then enter the marketplace "at risk" of patent infringement litigation. In re Tamoxifen Citrate Antitrust Litigation (466 F.3d 187, 206) (2d Cir. 2006). The provisions of Hatch-Waxman changed this calculus, the court opined, because the generic drug maker does not need to expend very much of its resources in developing its ANDA. Id. As a consequence, in the court's view, the generic drug maker has relatively "little to lose" in ANDA litigation. $I d$. at 207. The situation of the generic drug maker is in contrast to the patentee, who has lost the possibility of damages from the generic drug maker and can, at best, effectively obtain an injunction (either from the court or by the refusal of the FDA to provide regulatory approval until its Orange Book-listed patent(s) expire). The patentee's incentive is to prevent infringement, and a patentee may be willing to reach this result even if it needs to incur certain costs in the short term (i.e., reverse payments).

${ }^{54} I d$. at 209 ironically, citing an FTC position to this effect: "it would not be necessary, practical, or particularly useful for the Commission to embark on an inquiry into the merits of the underlying patent dispute when resolving antitrust issues in patent settlements." In the Matter of ScheringPlough Corp., et al. (136 F.T.C. 956, 998) (2003). It seems, however, that the FTC has changed its position on this point, because it argued that the "expected value" of the lawsuit at the time of settlement be considered in the "rule of reason" antitrust analysis. 


\section{K.E. Noonan}

to choose its preferred means of enforcement and no support for the notion that the Hatch-Waxman Act was intended to thwart settlements." 55 These appellate courts also looked at the consequences of banning reverse settlement agreements, deciding that not only would this reduce the frequency of such settlements but that, because the patentee would prevail at least some of the time, on balance generic drug entry would be delayed (Schering-Plough Corporation v. Federal Trade Commission (402 F.3d 1056, 1075-76) (11th Cir. 2005)). Finally, these courts of appeal have taken into consideration negative effects of the caustic environment of patent litigation on product innovation ${ }^{56}$ and the likelihood that other generic patent challengers will arise, which would make any attempt to "buy off" the competition unavailing and impractical. ${ }^{57}$ However, these courts also

${ }^{55}$ In re Ciprofloxacin Hydrochloride Antitrust Litigation (544 F.3d 1323, 1337) (Fed. Cir. 2008) abrogated by FTC v. Actavis, Inc. (133 S. Ct. 2223, 186 L. Ed. 2d 343) (U.S. 2013). Even Seventh Circuit Court Judge Richard Posner, a leader in the "law and economics" movement, seems to agree: "As Judge Posner [has] remarked, if 'there is nothing suspicious about the circumstances of a patent settlement, then to prevent a cloud from being cast over the settlement process a third party should not be permitted to haul the parties to the settlement over the hot coals of antitrust litigation."' Id. (quoting Asahi Glass Co. v. Pentech Pharmaceuticals, Inc. (289 F.Supp.2d 986, 992) (N.D. Ill. 2003)). And the Second Circuit agreed, in its Ciprofloxacin case, rejecting what it called a "post hoc determination of the potential validity" vel non of the '444 patent, which would be contrary to the statutory presumption of validity and "would work a revolution in patent law." Arkansas Carpenters Health \& Welfare Fund v. Bayer AG (604 F.3d 98, 103) (2d Cir. 2010) (quoting In re Ciprofloxacin Hydrochloride Antitrust Litigation (363 F.Supp.2d 514, 548) (E.D.N.Y. 2005)).

${ }^{56}$ For example, by amplifying the period of uncertainty around the drug manufacturer's ability to research, develop, and market the patented product or allegedly infringing product. This intensified guesswork involved with lengthy litigation cuts against the benefits proposed by a rule that forecloses a patentee's ability to settle its infringement claim. See In re Tamoxifen Citrate Antitrust Litigation (277 F.Supp.2d 121, 133) (E.D.N.Y. 2003) (noting that the settlement resolved the parties' complex patent litigation, and in so doing "cleared the field" for other ANDA filers).

${ }^{57}$ In the Tamoxifen case, for example, the Second Circuit termed unrealistic "the possibility that the patent holder will continue to buy out potential competition such that a settlement with one generic manufacturer protecting the patent holder's ill-gotten patent monopoly will be followed by other settlements with other generic manufacturers should a second, third, and fourth rise to challenge the recognized that sham or baseless litigation could trigger antitrust concerns and that the existence of a settlement would not exempt the parties of such liability. ${ }^{58}$ Absent such shenanigans, these courts of appeal have rejected the FTC's position that such agreements should be outlawed. ${ }^{59}$ The

patent" because "[e]very settlement payment to a generic manufacturer reduces the profitability of the patent monopoly. The point will come when there are simply no monopoly profits with which to pay the new generic challengers [] [I]t is unlikely that the holder of a weak patent could stave off all possible challengers with exclusion payments because the economics simply would not justify it." In re Tamoxifen Citrate Antitrust Litigation (466 F.3d 187, 211-12) (2d Cir. 2006) (quoting In re Ciprofloxacin Hydrochloride Antitrust Litigation (363 F.Supp.2d at 535)). Likewise, in the Ciprofloxacin case the Federal Circuit discounted plaintiffs' allegations that the settlement agreement hindered competition, in view of the fact that four other generic manufacturers had challenged the patent after the settlement at issue. In re Ciprofloxacin Hydrochloride Antitrust Litigation (544 F.3d 1323, 1338) (Fed. Cir. 2008).

${ }^{58}$ See, e.g., Walker Process Equipment, Inc. v. Food Machinery \& Chemical Corp. (382 U.S. 172, 179) (1965) (holding that there may be a violation of the Sherman Act when a patent is procured by fraud, but recognizing that a patent is an exception to the general rule against monopolies).

${ }^{59}$ For example, the Second Circuit in the Tamoxifen case opined:

We are unsure, too, what would be accomplished by a rule that would effectively outlaw payments by patent holders to generic manufacturers greater than what the latter would be able to earn in the market were they to defend successfully against an infringement claim. A patent holder might well prefer such a settlement limitation-it would make such a settlement cheaperwhile a generic manufacturer might nonetheless agree to settle because it is less risky to accept in settlement all the profits it expects to make in a competitive market rather than first to defend and win a lawsuit, and then to enter the marketplace and earn the profits ... [However,] [w] are not unaware of a troubling dynamic that is at work in these cases. The less sound the patent or the less clear the infringement, and therefore the less justified the monopoly enjoyed by the patent holder, the more a rule permitting settlement is likely to benefit the patent holder by allowing it to retain the patent. But the law allows the settlement even of suits involving weak patents with the presumption that the patent is valid and that settlement is merely an extension of the valid patent monopoly. So long as the law encourages settlement, weak patent cases will likely be settled even though such settlements will inevitably protect patent monopolies that are, perhaps, undeserved... "If courts do not discount the exclusionary power of the patent by the probability of the patent's being held invalid, then the patents most likely to be the subject of exclusion payments would be precisely those patents that have the most questionable validity. This concern, on its face, is quite powerful. But the answer to this 
distillation of these views became known as the "scope of the patent" test, whereby settlement agreements between branded and generic drug makers in ANDA litigation did not incur antitrust liability provided that the exclusionary behavior of the patentee was within the lawful scope of the presumptively valid patent and absent sham litigation or Walker Process fraud. ${ }^{60}$

The Third Circuit flatly rejected these views in its In re K-Dur Antitrust Litigation (686 F.3d 197) (3rd Cir. 2012) decision. ${ }^{61}$ Here the appellate panel agreed with the FTC that the reverse payment settlement agreement should be pre-

concern lies in the fact that, while the strategy of paying off a generic company to drop its patent challenge would work to exclude that particular competitor from the market, it would have no effect on other challengers of the patent, whose incentive to mount a challenge would also grow commensurately with the chance that the patent would be held invalid."

In re Tamoxifen Citrate Antitrust Litigation (466 F.3d 187, 211) (2d Cir. 2006) (quoting In re Ciprofloxacin Hydrochloride Antitrust Litigation (363 F.Supp.2d 514, 534) (E.D.N.Y. 2005)).

${ }^{60}$ See, e.g., Federal Trade Commission v. Watson Pharmaceuticals, Inc. (677 F.3d 1298, 1312) (11th Cir. 2012) ("Our Valley Drug, Schering-Plough, and Andrx decisions establish the rule that, absent sham litigation or fraud in obtaining the patent, a reverse payment settlement is immune from antitrust attack so long as its anticompetitive effects fall within the scope of the exclusionary potential of the patent.").

${ }^{61}$ The drug K-Dur 20 is a specific formulation of potassium chloride sold by Schering-Plough Co. (now owned by Merck) and protected by a formulation patent (U.S. Patent No. $4,863,743)$. Characterized as "separate from the FTCs challenge" (but no doubt motivated by it), the plaintiffs here filed various lawsuits that were consolidated in the District of New Jersey by the Judicial Panel on Multidistrict Litigation (fortuitously for plaintiffs and the FTC, in an appellate circuit that had not ruled on the reverse payment practice). The case named as plaintiffs drug wholesalers (Louisiana Wholesale Drug Co.) and retailers (CVS Pharmacy, Rite Aid, Walgreens, Eckerd, Safeway, Kroger, Albertson's, HyVee, and Maxi Drug) against Merck \& Co. (the successorin-interest to Schering-Plough) and Upsher-Smith Laboratories. Id. at 202. A special master appointed by the court filed a report and recommendation that the lawsuits be dismissed, based on Schering's right under the patents to "exclude infringing products until the end of [the patent's] term," and that reverse payment agreements warrant antitrust scrutiny only if they either exceeded the scope of the underlying patents or if the patent infringement lawsuits brought under the authority of the patents were objectively baseless (grounds that other appellate circuits had also considered in assessing the legality of reverse payment agreements). Id. at 208. sumptively illegal. According to the court, the proper approach is to evaluate any agreement alleged to be one that restrains trade by the rule of reason, and in this case determined that even this application of the antitrust analytical framework requires only a "quick look" application of the rule, because of the presumptive illegality of these agreements. ${ }^{62}$ This inquiry has three parts, according to the Third Circuit: There must be a showing of an anticompetitive effect on the market, which (if established) shifts the burden "to the defendant to show that the challenged conduct promotes a sufficiently pro-competitive objective." ${ }^{\prime 3}$ The antitrust plaintiff can rebut this showing if it can establish that the restraint on trade is not "reasonably necessary to achieve the [purportedly] pro-competitive objective" asserted by the antitrust defendant. ${ }^{64}$ The opinion rejected "precedent from other Circuits" finding reverse payment agreements to be lawful. ${ }^{65}$ The panel explained that it did not believe that the "scope of the patent" test was the appropriate test and should not entitle reverse payments to avoid antitrust scrutiny, because "that test [in the panel's view] improperly restricts the application of antitrust law

\footnotetext{
${ }^{62}$ Id. at 209 (citing State Oil Co. v. Khan (522 U.S. 3, 10) (1997)). The proper procedure under Third Circuit law is thus to use a "quick look" "rule of reason" analysis "based on the economic realities of the reverse payment settlement rather than the labels applied by the settling parties" and that "any payment from a patent holder to a generic patent challenger who agrees to delay entry into the market as prima facie evidence of an unreasonable restraint of trade." $I d$. at 218. In doing so, the court also "agree[d] ... with the FTC that there is no need to consider the merits of the underlying patent suit because "[a]bsent proof of other offsetting consideration, it is logical to conclude that the quid pro quo for the payment was an agreement by the generic to defer entry beyond the date that represents an otherwise reasonable litigation compromise,"' citing the commission's final order in this matter (that was overturned by the Eleventh Circuit). Id. at 219.

${ }^{63} I d$. at 209 .

${ }^{64} \mathrm{Id}$.

${ }^{65} I d$. at 210-14. See Arkansas Carpenters Health \& Welfare Fund v. Bayer AG (604 F.3d 98, 105) (2d Cir. 2010); In re Ciprofloxacin Hydrochloride Antitrust Litigation (544 F.3d 1323) (Fed. Cir. 2008); In re Tamoxifen Citrate Antitrust Litigation (466 F.3d 187) (2d Cir. 2006); Schering-Plough Corp. v. Federal Trade Commission (402 F.3d 1056) (11th Cir. 2005); and Valley Drug Company v. Geneva Pharmaceuticals, Inc. (344 F.3d 1294) (11th Cir. 2003).
} 


\section{K.E. Noonan}

and is contrary to the policies underlying the Hatch-Waxman Act and a long line of Supreme Court precedent on patent litigation and competition." $^{\text {66 }}$

The panel explicitly limited the scope of its decision to "reverse payments between patent holders and would be (sic) generic competitors in the pharmaceutical industry." ${ }^{37}$ The panel found that " $[t]$ he line that Congress drew between these competing objectives [of stimulating innovation and furthering the public interest] strongly supports the application of rule of reason scrutiny of reverse payment settlements in the pharmaceutical industry." ${ }^{68}$ And the panel limited the scope of its decision only to settlements that involve payments from the patentee to the putative generic competitor: " $[\mathrm{N}]$ othing in the rule of reason test that we adopt here limits the ability of the parties to reach settlements based on a negotiated entry date for

\footnotetext{
${ }^{66} I d$. at 214 . The opinion provided three grounds for this conclusion. First, the opinion stated that it creates "an almost unrebuttable presumption of patent validity" because of the fact that the settlement "enforces a presumption that the patent holder would have prevailed" in the underlying (and settled) ANDA litigation. Id. at 214. This presumption has (or should have) no substantive vitality, according to the panel, because it is merely "a procedural device and is not a substantive right of the patent holder." Id. (citing Stratoflex, Inc. v. Aeroquip Corp. (713 F.2d 1530, 1534) (Fed. Cir. 1983)). The opinion also believed that using the presumption of validity to uphold reverse payment agreements was "particularly misguided" when the basis for the underlying patent infringement defense is noninfringement (as it was in this case), because the burden is properly on the patentee, not the challenger, to prove infringement. Id. at 214. The panel opinion further "question[ed] the assumption" that subsequent ANDA filers will come forward to challenge "weak" patents. Id. at 215.

${ }^{67} I d$. at 216. The Third Circuit panel considered perceived pernicious effects on reverse settlements as being directed to first ANDA filers, which it asserts are the "most motivated" because of the promise of 180 days of market exclusivity. Id. at 215. The panel also cited several Supreme Court cases for the proposition that patent rights are "a limited exception to a general rule of the free exploitation of ideas" and that "the public interest supports judicial testing and elimination of weak patents." Id.

${ }^{68} \mathrm{Id}$. at 217. It is clear that the panel was motivated at least in part by its perception, as argued by the FTC, that reverse payment settlement agreements were contrary to and in contravention of congressional goals of "increas[ing] the availability of low cost generic drugs" (despite findings in other circuits that in some circumstances reverse payment settlements do just that). Id.
}

marketing of the generic drug: the only settlements subject to antitrust scrutiny are those involving a reverse payment from the name brand manufacturer to the generic challenger." ${ }^{39}$

\section{SUPREME COURT DECISION}

The U.S. Supreme Court, in the case now styled FTC v. Actavis, Inc. ${ }^{70}$ reversed the Eleventh Circuit's Watson decision. In a 5-3 ruling, Justice Breyer's opinion ${ }^{71}$ reversed the lower court's decision to dismiss the FTC's complaint that a reverse payment settlement was anticompetitive and violated the antitrust laws. But the Court refused to accept the FTC's position that such agreements are presumptively unlawful, holding that lower courts should apply an antitrust "rule of reason" analysis when evaluating such agreements.

The Court held that reverse payment settlement agreements can "sometimes violate the antitrust laws," and thus that the district court should not have dismissed the case brought by the FTC. The opinion focused on the risk to the consuming public posed by such settlements in cases in which the patent is invalid or not infringed. According to the majority, although the court was willing to accept that the agreement's "anticompetitive effects fall within the scope of the exclusionary potential of the patent," this fact was not sufficient to "immunize the agreement from antitrust attack."72 The majority's concern was that although the holder of a valid

\footnotetext{
${ }^{69} \mathrm{Id}$. at 217-18. According to the court, "the vast majority of pharmaceutical patent settlement [will be] unaffected" by its ruling. $I d$. at 218.

${ }^{70}$ See 133 S. Ct. 2223, 186 L. Ed. 2d 343 (2013). The court granted certiorari in this case, rather than the K-Dur case, based on the FTC's petition urging that the Actavis case was limited to the FTC action and hence presented an administrative law question. See Kevin E. Noonan, "FTC asks Supreme Court to play favorites in reverse payment settlement agreement cases," Patentdocs.org (October 16, 2012), www .patentdocs.org/2012/10/ftc-asks-supreme-court-to-playfavorites-in-reverse-payment-settlement-agreement-cases .html

${ }^{71}$ Writing for the majority that included Justices Breyer, Kennedy, Ginsburg, Sotomayor, and Kagan. FTC v. Actavis, Inc. (133 S. Ct. 2223, 186 L. Ed. 2d 343) (2013).

${ }^{72}$ Id. at 2230 (quoting Federal Trade Commission v. Watson Pharmaceuticals, Inc. (677 F.3d 1298, 1312) (2012)).
} 
patent may be exempt from antitrust liability when enforcing the exclusionary right, ANDA litigation involves an allegation that either the patent is invalid (in which case the immunization is lost) or the generic product does not infringe (in which case the patent cannot be enforced against the noninfringing generic drug). Accordingly, such agreements "tend to have significant adverse effects on competition." ${ }^{\text {"73 }}$ For this reason the majority believed that "it would be incongruous to determine antitrust legality by measuring the settlement's anticompetitive effects solely against patent law policy, rather than by measuring them against procompetitive antitrust policies as well." 74 Finally, the court found that the "precompetitive" purposes of the Hatch-Waxman Act are consistent with having courts apply antitrust principles to reverse payment settlement agreements in ANDA litigation.

The majority recognized the Eleventh Circuit's concern that "antitrust scrutiny of a reverse payment agreement would require the

\footnotetext{
${ }^{73} I d$. at 2231.

${ }^{74}$ Support for this proposition (vigorously disputed by the dissenting justices; see below) can be found in Justice Breyer's opinion in several of the court's earlier cases, including Walker Process Equipment, Inc. v. Food Machinery \& Chemical Corp. (382 U.S. 172, 174) (1965) (incongruously, a case that established one of the grounds for finding reverse payment settlement agreements unlawful, i.e., asserting a patent obtained by "fraud on the Patent Office"); United States v. Line Material Co. (333 U.S. 287, 308) (1948) (retail price-setting between patentees); and United States v. United States Gypsum Co. (333 U.S. 364, 390-391) (1948) (both cases from those days when the only patents that were valid were those the court had not yet ruled upon). The opinion also cited several earlier cases where settlement agreements (not in the Hatch-Waxman context) were held to violate the antitrust laws. These cases included United States v. Singer Manufacturing Co. (374 U.S. 174) (1963) (in which the issue was collusion between three patentees to enforce the strongest patent against their competitors); United States $v$. New Wrinkle, Inc. (342 U.S. 371, 378) (1952) (more price fixing); and Standard Oil Co. (Indiana) v. United States (283 U.S. 163) (1931) (patentees setting royalty rates). The question of whether any of these situations are at all relevant to reverse payment settlement agreements was not addressed in the opinion, which merely seemed content to find cases where the court has in the past found that settlement "agreements are not outside the scope of antitrust attack" (and does not consider whether the circumstances surrounding this prior approbation is in any way related to the question before the court).
}

parties to litigate the validity of the patent in order to demonstrate what would have happened to competition in the absence of the settlement," an outcome that "will prove time consuming, complex, and expensive." to this concern, the majority offered five "considerations" as its basis for its holding that the FTC should be permitted to establish an antitrust violation:

First, the specific restraint at issue has the potential for genuine adverse effects on competition ... The payment in effect amounts to a purchase by the patentee of the exclusive right to sell its product, a right it already claims but would lose if the patent litigation were to continue and the patent were held invalid or not infringed by the generic product. $^{76}$

Second, these anticompetitive consequences will at least sometimes prove unjustified." The majority's concern is that a court cannot tell without inquiry whether a particular reverse payment settlement agreement is or is not "justified" under antitrust principles. "Where a reverse payment reflects traditional settlement considerations, such as avoided litigation costs or fair value for services, there is not the same concern that a patentee is using its monopoly profits to avoid the risk of patent invalidation or a finding of noninfringement. In such cases,

\footnotetext{
${ }^{75}$ Actavis (133 S. Ct. at 2234, 186 L. Ed. 2d 343) (2013).

${ }^{76} \mathrm{Id}$. at 2234 (internal quotations omitted) (emphasis in original). The opinion also stated this concern as "[t]he patentee and the challenger gain; the consumer loses," citing academic sources and amicus briefs for the proposition that "there are indications that patentees sometimes pay a generic challenger a sum even larger than what the generic would gain in profits if it won the paragraph IV litigation and entered the market." Id. at 2235. Under these circumstances "a payment of this size ... may instead provide strong evidence that the patentee seeks to induce the generic challenger to abandon its claim with a share of its monopoly profits that would otherwise be lost in the competitive market." $I d$. And the majority disparaged the idea that entering into such an agreement would merely entice other generic challengers to get in line to be bought off by the patentee, based on the loss of the 180-day exclusivity for later ANDA filers and the 30-month delay in FDA approval raised by ANDA litigation against such a subsequent filer. Id. These considerations convinced the majority that, rather than producing an untenable situation in which the owner of a weak patent cannot possibly "buy [] off" all potential competitors, the HatchWaxman regime in fact produces a critical generic challenger, the first filer, who if successfully bought off by a reverse payment settlement agreement will effectively chill future challenges by other generic drug makers. Id.
} 


\section{K.E. Noonan}

the parties may have provided for a reverse payment without having sought or brought about [] anticompetitive consequences ... ${ }^{77}$

Third, where a reverse payment threatens to work unjustified anticompetitive harm, the patentee likely possesses the power to bring that harm about in practice." Once again the majority is concerned with the size of the payment, which a court can use to be "a strong indicator of [market] power. $^{78}$

"Fourth, an antitrust action is likely to prove more feasible administratively than the Eleventh Circuit believed." Here the majority finds the Eleventh Circuit "throws the baby out with the bathwater" by refusing to apply antitrust principles due to the difficulties of litigating patent infringement and validity (when, of course, the appellate court was merely recognizing that the impetus for these settlements would disappear should the parties be required to litigate in an antitrust context what they avoiding litigating in an ANDA context). ${ }^{79}$

"Fifth, the fact that a large, unjustified reverse payment risks antitrust liability does not prevent litigating parties from settling their lawsuit." Here, the majority posits that the parties can settle an ANDA dispute in "other ways, [] by allowing the generic manufacturer to enter the patentee's market prior to the patent's expiration, without the patentee paying the challenger to stay out prior to that point."

The majority summarized these considerations as follows:

In sum, a reverse payment, where large and unjustified, can bring with it the risk of significant anticompetitive effects; one who makes such a

\footnotetext{
${ }^{77} I d$. at 2235-36. This uncertainty formed the basis for the majority to conclude that the district court erred in dismissing the FTC's complaint, because by doing so it denied the commission the chance to establish whether or not there were such justifications for the agreement. ${ }^{78} I d$.

${ }^{79} I d$. at 2237 . According to the majority, "it is normally not necessary to litigate patent validity to answer the antitrust question" (except for sham litigation), because "[a]n unexplained large reverse payment itself would normally suggest that the patentee has serious doubts about the patent's survival." Id. at 2236.

${ }^{80} I d$. at 2237 . Once again the majority return to the existence of a payment, saying that "the basic antitrust question" comes down to the reasons for the payment (and, of course, a court's determination of whether those reasons are valid).
}

payment may be unable to explain and to justify it; such a firm or individual may well possess market power derived from the patent; a court, by examining the size of the payment, may well be able to assess its likely anticompetitive effects along with its potential justifications without litigating the validity of the patent; and parties may well find ways to settle patent disputes without the use of reverse payments. In our view, these considerations, taken together, outweigh the single strong consideration-the desirability of settlements - that led the Eleventh Circuit to provide near-automatic antitrust immunity to reverse payment settlements. ${ }^{81}$

The FTC did not entirely win the day with the majority, however; the Court rejected the commission's suggestion that these agreements should be presumptively unlawful and that the rule of reason be applied using a "quick look" or other shortcut, which the majority noted was permissible only in instances where "an observer with even a rudimentary understanding of economics could conclude that the arrangements in question would have an anticompetitive effect on customers and markets." ${ }^{12}$ Instead, the Court held that the FTC must establish antitrust liability using a "rule of reason" analysis, and in doing so, district courts can structure the inquiry to avoid litigating patent validity, leaving it to these "lower" courts to determine exactly how that may be accomplished.

Chief Justice Roberts wrote the dissent, ${ }^{83}$ applying much of the same precedent and coming to the opposite conclusion: The existence of a patent, properly cabined within its proper scope, should be enough to justify a reverse payment settlement of ANDA litigation. The dissent asserted that the majority would "use an-

\footnotetext{
${ }^{81} I d$.

${ }^{82} I d$. at 2237, quoting Justice Breyer's concurring-in-part and dissenting-in-part opinion in California Dental Association v. FTC (526 U.S., 756, 770) (1999). This treatment is not justified for reverse payment settlement agreements according to the majority, because "the likelihood of a reverse payment bringing about anticompetitive effects depends upon its size, its scale in relation to the payor's anticipated future litigation costs, its independence from other services for which it might represent payment, and the lack of any other convincing justification." Id.

${ }^{83}$ Joined by Justices Scalia and Thomas (Justice Alito recused himself from this case).
} 
titrust law's amorphous rule of reason to inquire into the anticompetitive effects of such settlements" instead of following "well-established" principles of patent law. ${ }^{84}$ Patent law "provides an exception to antitrust law, and the scope of the patent-i.e., the rights conferred by the patent-forms the zone within which the patent holder may operate without facing antitrust liability," according to Chief Justice Roberts, and "[t]his should go without saying, in part because we've said it so many times." 85

${ }^{84} I d$. at 2238 (Roberts, J., dissenting).

${ }^{85}$ Id. (citing Walker Process Equipment, Inc. v. Food Machinery \& Chemical Corp. (382 U.S. 172, 177) (1965); United States v. Line Material Co. (333 U.S. 287, 300) (1948); United States v. General Electric Co. (272 U.S. 476, 485) (1926); and Simpson v. Union Oil Co. of California (377 U.S. 13, 24) (1964)). Besides finding no support in the patent law or other statute, the dissent objected to the majority's ruling because it "will discourage the settlement of patent litigation." Id. The dissent also noted that the only time a settlement was found to violate antitrust law in past Supreme Court precedent was when the settlement went beyond the boundaries of the patent grant. Id. at 2239, citing United States v. Singer Manufacturing Co. (374 U.S. 174, 196-97) (1963), unless the patents are obtained by fraud (Walker Process) or the patentee engaged in sham litigation, citing Professional Real Estate Investors, Inc. v. Columbia Pictures Industries, Inc. (508 U.S. 49, 60-61) (1993). The dissenting opinion dissected the authority cited by the majority and provided context or other statements from these cases that contradicted or threw a different light on these decisions contrary to the majority's views. Id. at 2240-42. And the history of the application of antitrust law in the patent context is telling:

The majority is therefore right to suggest that these "precedents make clear that patent-related settlement agreements can sometimes violate the antitrust laws." Ante, at 2232 (emphasis added). The key word is sometimes. And those some times are spelled out in our precedents. Those cases have made very clear that patent settlements - and for that matter, any agreements relating to patents-are subject to antitrust scrutiny if they confer benefits beyond the scope of the patent. This makes sense. A patent exempts its holder from the antitrust laws only insofar as the holder operates within the scope of the patent. When the holder steps outside the scope of the patent, he can no longer use the patent as his defense. The majority points to no case where a patent settlement was subject to antitrust scrutiny merely because the validity of the patent was uncertain. Not one. It is remarkable, and surely worth something, that in the 123 years since the Sherman Act was passed, we have never let antitrust law cross that Rubicon. Id. at 2242.

According to the chief, "settling a patent claim cannot possibly impose unlawful anticompetitive harm if the patent
The dissenting justices contended that the majority's fancy that the antitrust question can be answered without considering the validity of the patent is unrealistic, and "depriving [the patentee] of such a defense-if that's what the majority means to do-defeats the point of the patent, which is to confer a lawful monopoly on its holder." ${ }^{86}$ And the dissent evinced little faith in the many presumptions underlying the majority opinion, regarding the mechanics and purpose of the Hatch-Waxman Act or how district courts will apply the Court's decision. $^{87}$

\section{CONCLUSION}

The Court's Actavis decision will likely end reverse payment settlement agreements, making generic competition less likely. Unable to settle, innovator patentees will litigate every case to conclusion to avoid antitrust scrutiny involving the same or similar infringement and validity questions better settled in ANDA litigation. Coupled with the FTC's position that transfer

\footnotetext{
holder is acting within the scope of a valid patent and therefore permitted to do precisely what the antitrust suit claims is unlawful." Id. at 2244 (emphasis in original).

${ }^{86} \mathrm{Id}$. (emphasis in original).

${ }^{87} I$ d. at 2245 ("Good luck to the district courts that must, when faced with a patent settlement, weigh the likely anticompetitive effects, redeeming virtues, market power, and potentially offsetting legal considerations present in the circumstances."'). The policy implications are bleak regarding benefits to the consumer:
}

The irony of all this is that the majority's decision may very well discourage generics from challenging pharmaceutical patents in the first place. Patent litigation is costly, time consuming, and uncertain... Generics "enter this risky terrain only after careful analysis of the potential gains if they prevail and the potential exposure if they lose." ... Taking the prospect of settlements off the table-or limiting settlements to an earlier entry date for the generic, which may still be many years in the future-puts a damper on the generic's expected value going into litigation, and decreases its incentive to sue in the first place. The majority assures us, with no support, that everything will be okay because the parties can settle by simply negotiating an earlier entry date for the generic drug manufacturer, rather than settling with money ... But it's a matter of common sense, confirmed by experience, that parties are more likely to settle when they have a broader set of valuable things to trade. Id. at 2247 (citations omitted). 


\section{K.E. Noonan}

of "anything of value" from the branded drug maker to a generic competitor should also merit antitrust scrutiny, there is now little advantage for either party in an ANDA lawsuit to settle and thus incur greater costs and risk that should deter rather than incentivize generic challenges. This is not the consequence that the majority likely envisioned, but it is almost certainly the outcome that will result from this decision. 


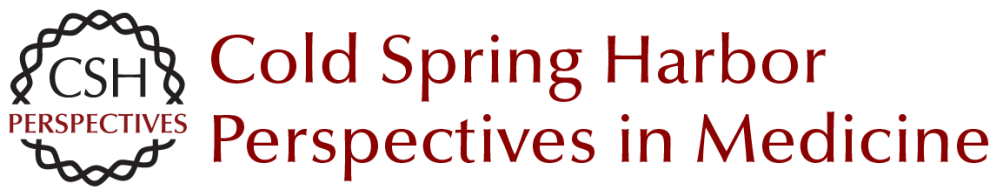

\section{The Role of Regulatory Agencies and Intellectual Property: Part II}

Kevin E. Noonan

Cold Spring Harb Perspect Med 2015; doi: 10.1101/cshperspect.a020834 originally published online March 16, 2015

Subject Collection Intellectual Property in Molecular Medicine

Patentability of Stem Cells in the United States Sarah E. Fendrick and Donald L. Zuhn, Jr.

Inventorship and Authorship Antoinette F. Konski and Linda X. Wu

The Patentability of Stem Cells in Australia Jenny Petering and Prue Cowin

Impact of America Invents Act on Biotech Intellectual Property

Amanda Murphy, Michael Stramiello, Jonathan Stroud, et al.

Introduction to Intellectual Property: A U.S.

Perspective

Amanda Murphy, Michael Stramiello, Stacy Lewis, et al.

The Role of Regulatory Agencies and Intellectual Property: Part I

Kevin E. Noonan

Canada's Patented Medicines (Notice of Compliance) Proceedings and Intellectual

Property

Henry Bian and Conor McCourt

Patentability of Genes: A European Union

Perspective

Paul Cole
The Impact of Myriad on the Future Development and Commercialization of DNA-Based Therapies and Diagnostics

Michele Wales and Eddie Cartier

Protecting Traditional Knowledge Related to

Biological Resources: Is Scientific Research

Going to Become More Bureaucratized?

Prashant Reddy and Malathi Lakshmikumaran

Protecting Trade Secrets in Canada

Noel Courage and Janice Calzavara

Inherent Anticipation in the Pharmaceutical and

Biotechnology Industries

Michael Goldman, Georgia Evans and Andrew Zappia

The Role of Regulatory Agencies and Intellectual

Property: Part II

Kevin E. Noonan

Baseball Bats and Chocolate Chip Cookies: The Judicial Treatment of DNA in the Myriad Genetics Litigation lan Binnie and Vanessa Park-Thompson

The Impact of Myriad and Mayo: Will

Advancements in the Biological Sciences $\mathrm{Be}$

Spurred or Disincentivized? (Or Was Biotech

Patenting Not Complicated Enough?) Jennifer Gordon

Trade Secrets in Life Science and Pharmaceutical Companies

Tara Nealey, Ronald M. Daignault and Yu Cai

For additional articles in this collection, see http://perspectivesinmedicine.cshlp.org/cgi/collection/ 